\title{
EXPECTATIONS OF AND SATISFACTION WITH THE SOUTH AFRICAN POLICE SERVICE IN THE RUSTENBURG AREA*
}

\author{
E. KLEYN \\ S. ROTHMANN \\ L.T.B. JACKSON \\ WorkWell: Research Unit for People, Policy and Performance, \\ North-West University, Potchefstroom Campus
}

\begin{abstract}
Little quantitative research has been published on expectations of and satisfaction with the South African Police Service (SAPS) from the perspective of the community and the police members themselves. The objective of this study was to determine the expectations and satisfaction of both the community and the police regarding policing in the Rustenburg area. A cross-sectional survey design was used. Stratified random samples of both police members $(N=101)$ and community members $(N=418)$ were taken in the Rustenburg area. The results showed that members of the community and the police differ regarding policing priorities. Most police members reported that their performance in serving the community was good. A total of $47 \%$ of community members who had contact with the police showed little confidence in the police.
\end{abstract}

\section{OPSOMMING}

Min kwantitatiewe navorsing ten opsigte van verwagtinge en tevredenheid met die Suid-Afrikaanse Polisiediens (SAPD) vanuit die perspektief van die publiek en die polisiebeamptes is tot op hede gepubliseer. Die doel van hierdie studie was om te bepaal wat die verwagtinge en tevredenheid van die publiek sowel as die polisie ten opsigte van polisiëring in die Rustenburg-gebied is. ' $n$ Dwarsdeursnee-opnameontwerp is gebruik. 'n Gestratifiseerde ewekansige steekproef is geneem van polisiebeamptes $(N=101)$ sowel as van lede van die gemeenskap $(N=418)$ in die Rustenburg-gebied. Die resultate het aangetoon dat lede van die gemeenskap en polisiebeamptes ten opsigte van die prioriteite van polisiëring verskil. Die meeste polisielede het gerapporteer dat hul prestasie in diens van die publiek goed is. 'n Totaal van $47 \%$ van lede van die publiek wat kontak met die polisie gehad het, het aangedui dat hulle min vertroue in die polisie het.

Future prosperity in South Africa depends on economic growth and development. However, Barlow and Barlow (1999, p. 14-15) argued that even "ordinary crime can disrupt the maintenance of an orderly, productive, and profitable society and the suppression of crime can help to maintain order." According to these authors, an effective and efficient police service is important for at least two reasons. Firstly, it is important for securing and maintaining social order, which provides the business confidence necessary for owners of capital to invest and the cycle to begin. Secondly, it is important so that the rule of law can prevail, otherwise our society will lack not only order but also the environment essential to social and economic progress. It can therefore be argued that to stimulate economic growth and development in South Africa, an effective and efficient police service is important, seeing that crime and violence can inhibit growth and development.

Since 1993 the traditional view of the South African Police Service (SAPS) has changed from that crime fighters to that of community policing (Pelser, Schnetler \& Louw, 2002). According to the South African Department of Safety and Security's Community Policing Policy Framework and Guidelines (1997), community policing can be defined as a philosophy that guides police management styles and operational strategies and emphasises the establishment of a police-community partnership and a problem-solving approach that is responsive to the needs of the community. A major objective of community policing is to establish an active partnership between the police and the community through which crime, service delivery and police-community relations can be analysed jointly and appropriate solutions designed and implemented (Department of Safety and Security, 1997).

The movement from the traditional crime-fighting model to a community-based model of policing in South Africa brings about change in the definition of policing. Whereas it used to be

Requests for copies should be addressed to: S Rothmann, WorkWell: Research Unit for People, Policy and Performance, North-West University, Potchefstroom Campus, Potchefstroom, 2520 a "police force," it is now a "police service." Therefore it can be argued that, as for all other complex agencies involved in service delivery, it is important for the police to know how satisfied or dissatisfied their clients are. Moreover, it is important to discover the factors that affect citizen satisfaction. According to Couper (1983), the use of measures such as response time, crime arrests or clearance rates is inconsistent with the new philosophies of policing, because such measures fail to address the role of the public as the consumer of policing services. If the police are to serve the public effectively, a constructive working relationship must exist between law enforcement officials and citizens (Worrall, 1999).

Community policing has been presented as a tool to enable police officers to prevent and control crime and to improve police-citizen relations, but there may be obstacles that obstruct its successful implementation and sustainability. The extent to which the public is willing to co-operate in community policing appears to be the product of a number of problems (Reisig \& Giacomazzi, 1998). This includes attitudes toward community policing (expectations and perceptions), fear of retaliation and poor pre-existing relations between the police and neighbourhood residents According to Beck, Boni and Packer (1999), police members should become more aware of the critical role of public perceptions of and experiences with the police in any determination of police effectiveness.

It is important to study the public's opinion of police services for at least four reasons. Firstly, because members of the public are the consumers of police services, it is vital to obtain their evaluation of the police service received (Flanagan, 1985). Secondly, positive images of the police are necessary for the police to function effectively (Murty, Komanduri, Julian \& Smith, 1990). Negative attitudes towards the police, in contrast, result in mutual ill feelings, a lack of respect, disorder and inefficient police functioning (Radelet, 1986). Thirdly, the information may yield important insights not only into citizens' 
confidence in the police, but also into the correlates of their confidence (Hero \& Durand, 1985). Lastly, to be able to consult effectively with the community, police members should have a good understanding of what the public think they as police are currently doing and what they (the public) would prefer the police to do (Beck et al., 1999).

It is possible to study public opinion of police services through the use of public attitude surveys. In the first instance these should focus on the discrepancies between current and preferred priorities of police activities. Secondly, it is necessary to determine the level of consensus between the police and the public's expectations about the appropriate role for police, since consensus is essential if the co-operative effort of community policing is to be effective (Beck et al., 1999). Beck et al. (1999) noted that there was no research determining the public's understanding of current police priorities, and almost no research examining how police officers perceive their role and what they believe their role should be.

Little quantitative research has been published on public expectations of and satisfaction with the South African Police Service (SAPS). Furthermore, little attention has been paid in academic literature to the issue of the relationships between the police and the public from the viewpoints of the police clientele and the police themselves. Previous research into community policing has several drawbacks. Firstly, only a limited number of studies have focused on police officers. Secondly, researchers largely studied citizens' perceptions of community policing rather than assessing attitudes of police officers on this subject. Thirdly, research into community policing tends to ignore the service component of community policing. Fourthly, community-policing studies have been criticised for their lack of statistical rigor.

There is thus a need to determine the community's expectations of and satisfaction with the SAPS. Information about the expectations and satisfaction of the community will enable management to implement plans to ensure the effective implementation and sustainability of community policing. Furthermore, scientific information is also needed about how police members perceive their own jobs and services to the community. This information could be used to improve the effectiveness of the SAPS.

The first objective of this study was to determine the community's expectations and satisfaction with the SAPS and to determine whether there are differences between Afrikaans-, English- and Tswana-speaking community members. A second objective was to determine the perceptions of the police personnel in the Rustenburg area regarding their functions.

\section{Community satisfaction and service expectations}

Boundary-spanning personnel such as hairdressers, travel agents and police officers interface directly with their customers. These service providers usually market their services to consumers while they simultaneously carry out operational functions. Hubbert, Sehorn and Brown (1995) argued that both the customer and the provider of a service bring about certain expectations to the service encounter, which then shape the perceptions of such a service encounter. They also believe that expectations for service or product performance represent a specific predetermined standard and that customers usually use this standard to compare perceived performance when they evaluate such a service or product.

The relationship between expectations and satisfaction is not necessarily a simple one. Members of the public who have very high expectations of the police are likely to become frustrated when the police fail to meet these expectations
(Carter, 1985). Such expectations may be rooted in what people believe they are entitled to expect from the police (Erez, 1984). According to Fosam and Grimsley (1998), dissatisfaction of the public in the United Kingdom was a result of the police having the wrong perception about what the public wanted from the service.

One concept, which is especially applicable to community policing, also referred to as police-citizen encounters, is expectancy disconfirmation. Disconfirmation can be seen as the extent to which customers' perceptions match their expectations. Expectations, then, provide the baseline from which to compare perceptions of product or service performance (Reisig \& Chandek, 2001).

According to Reisig and Chandek (2001), the expectancy disconfirmation model postulates that consumer satisfaction is a response to the congruency between an individual's expectations and the actual performance of a service or product. The expectancy disconfirmation model can be conceptualised as a four-stage process (Reisig \& Chandek, 2001). Firstly, the consumer formulates expectations regarding a product or a service, in other words, what the customer estimates or believes services or performance should be like. Secondly, the individual to a certain extent attributes certain beliefs to the performance of the service or product. Thirdly, the customer measures the service performance against his/her initial expectations. In the final stage the customer determines how well the service measures up to his/her initial expectations.

Therefore, it can be argued that the customer's type of disconfirmation ("better than - positive," "worse than negative," or "equal to (zero" what was expected) will directly impact on satisfaction (Reisig \& Chandek, 2001). However, although it seems as if disconfirmation has the largest effect on customer satisfaction, research also shows that expectation directly impacts on satisfaction. For example, individuals with lower expectations often report higher levels of satisfaction.

If the above is applied to community policing, satisfaction can be viewed as a function of the interrelationship between what citizens expect from the police and their perceptions of police performance. The findings of Reisig and Chandek (2001) show a significant correlation between the levels of service an individual receives and his/her satisfaction with the way the police handled the encounter. It is therefore not surprising that Choong (2001) argues that ensuring the satisfaction of customers has become the most accepted strategy for an organisation's success and survival.

The results of Reisig and Chandek (2001) indicate that police behaviour is the most salient determinant of satisfaction among citizens encountering the police (both voluntarily and involuntarily). If citizen satisfaction is used as a performance measure of police-citizen encounters, these findings support efforts to encourage police officers to display civility when interacting with citizens. The core of community policing then requires, among other things, an organisational commitment to problem-solving and customer satisfaction (Reisig \& Giacomazzi, 1998).

\section{METHOD}

\section{Research design}

A qualitative design (interviews and focus groups) was used to identify items that could be used in questionnaires. A crosssectional survey design was then used to describe the information on the population collected at that time. This design (Shaughnessy \& Zechmeister, 1997) can also be used to evaluate interrelationships among variables within a population. 
According to Shaughnessy and Zechmeister (1997), this design is also ideal to describe and predict functions associated with correlative research.

\section{Sample}

The study population includes police members $(N=101)$ as well as community members $(N=418)$ served by these police members of police stations in the Rustenburg area of the North West Province. Both samples were randomly selected. A total of $42 \%$ of the participants in the police sample were male and $58 \%$ were female, with a mean age of 35,76 . Fifty nine percent of the police sample were matriculated, $7 \%$ were university graduates and 33\% college/technikon graduates. Thirty three percent of the police members were single, $56 \%$ were married and $7 \%$ divorced. A total of 73 of the participants in the community sample were Afrikaansspeaking, 103 were English-speaking and 242 were Tswanaspeaking. Fifty four percent of the participants in the community sample were male. Their ages ranged between 12 and 79 (Rothmann, 2002).

\section{Measuring instrument}

Following Beck et al. (1999), parallel forms of the Public Attitude Survey (PAS) were developed to measure both the public's and the police's perceptions and expectations of police events. For the purpose of this study, 38 police activities were selected to cover the major police functions of crime prevention, peacekeeping and service provision. The activities were adapted in consultation with senior and operational police officers and include questions like "Advise people on personal safety", "Respond to emergencies", and "Deal with sexual violence and crime against women and children." The 38 activities were divided into seven dimensions, namely: provide advice (6 items), investigate crime (11 items), station duties (6 items), crime prevention (4 items), non-emergency assistance (3 items), family issues (5 items) and security (3 items) (Rothmann, 2002).

The survey was then divided into two sections. In the first section, namely, "At present", respondents were asked to indicate on a five-point scale ( $1=$ very low, to $5=$ very high $)$ what priority they think police currently give to each of the 38 activities. In the second section, namely "Preferred", respondents were asked to indicate on a five-point scale (1 $=$ very low, to $5=$ very high) what priority they think police should give to each of the 38 activities. The aim of this survey is to determine what respondents (public and police) believe police priorities are at present; what respondents (public and police) think police priorities should be; and what the level of consensus is between perceptions of the police and the public (Beck et al., 1999, p. 2).

\section{Procedure}

The study, which formed part of a larger project on attitudes towards community policing in the North West Province, was initiated during October 2000 after discussions with the Strategic Management Services of the SAPS in Pretoria. During 2001, the project was planned and funding for the project was obtained from the National Research Foundation. During January 2002 the Potchefstroom University for Christian Higher Education and the University of North West (UNW) implemented the project. The project proposal was presented to the Provincial Commissioner of the SAPS in the North West Province as well as the Area Commissioner in the Rustenburg area to obtain the support and collaboration of the SAPS. Literature searches were done and interviews as well as focus groups (including police experts) were conducted to develop the measuring instruments.

The English questionnaires were developed and translated into Afrikaans and Tswana by professional translators. A process of back-translation was followed to ensure that the meaning of the words in the different languages was the same. Thereafter, they were presented to members of the police and the community to check for face validity and final changes were made to them. The measuring battery of the police was only compiled in English. A total of 12 field workers (who were able to speak Afrikaans, English and/or Tswana) were used to administer the questionnaires. The researchers, assisted by language practitioners, trained the field workers prior to the start of fieldwork.

Randomly selected police stations were informed a month prior to the date of the fieldwork. Fieldwork took place during July 2002. Members of the SAPS on duty that day were included in the study, while community members were randomly selected at taxi ranks, in town and via door-to-door selection in different areas of the town and neighbourhoods. The data were captured on a computer programme and checked for mistakes. Finally, the data set was prepared for statistical analysis.

\section{Data analysis}

The data analysis was carried out with the help of the SAS program (SAS Institute, 2000). Cronbach alpha coefficient and inter-item correlation coefficients were used to assess the internal consistency of the measuring instruments (Clark \& Watson, 1995). Coefficient alpha conveys important information regarding the proportion of error variance contained in a scale. According to Clark and Watson (1995), the average inter-item correlation coefficient (which is a straightforward measure of internal consistency) is a useful index to supplement information supplied by coefficient alpha. However, unidimensionality of a scale cannot be ensured simply by focusing on the mean inter-item correlation - it is also necessary to examine the range and distribution of these correlations. Confirmatory factor analyses were used to assess the validity of the constructs and, if necessary, items with values lower than 0,45 were removed from analyses.

Descriptive statistics (e.g. means, standard deviations, skewness and kurtosis) were used to analyse the data. T-tests and one-way analysis of the variance (ANOVA) were used to determine differences between the subgroups in the sample. The following formula was used to determine the practical significance of differences (d) when t-tests were used (Steyn, 1999):

$d=\frac{\text { Mean }_{A}-\text { Mean }_{B}}{S D_{\text {MAX }}}$

where

$\mathrm{Mean}_{A}=$ Mean of the first group

Mean $_{B}=$ Mean of the second group

$S D_{\mathrm{MAX}}=$ Highest standard deviation of the two groups

The following formula was used to determine the practical significance of means of more than two groups (Steyn, 1999):

$$
\begin{aligned}
& d=\frac{\text { Mean }_{A}-\text { Mean }_{B}}{\text { Root MSE }} \\
& \text { where } \\
& \text { Mean }_{A}=\text { Mean of the first group } \\
& \text { Mean }_{B}=\text { Mean of the second group } \\
& \text { Root MSE = Root Mean Square Error }
\end{aligned}
$$

A cut-off point of 0,50 (medium effect, Cohen, 1988) was set for the practical significance of differences between means.

\section{RESULTS}

Descriptive statistics, Cronbach alpha coefficients and the inter-item correlation coefficients of the PAS for police officers $(N=101)$ in the Rustenburg area are reported in Table 1. 
TABLE 1

DESCRIPTIVE STATISTICS, CRONBACH ALPHA COEFFICIENTS AND INTER-ITEM CORRELATION COEFFICIENTS OF THE PAS FOR SAPS MEMBERS IN THE RUSTENBURG AREA $(N=101)$

\begin{tabular}{lcccccc}
\hline Test and items & Mean & $\boldsymbol{S D}$ & Skewness & Kurtosis & Inter-item $\boldsymbol{r}$ & $\alpha$ \\
\hline PAS - Present & & & & & & \\
Advice & 20,66 & 5,09 & 0,21 & 0,24 & 0,53 & 0,87 \\
Investigation & 37,98 & 8,68 & $-0,56$ & 0,07 & 0,55 & 0,93 \\
Station duties & 20,16 & 5,30 & 0,10 & 0,30 & 0,52 & 0,87 \\
Crime prevention & 13,00 & 3,94 & $-0,19$ & 0,27 & 0,46 & 0,77 \\
Assistance & 9,19 & 2,78 & $-0,48$ & 0,07 & 0,40 & 0,67 \\
Family issues & 16,86 & 4,52 & $-0,61$ & 0,34 & 0,45 & 0,80 \\
Security & 10,80 & 2,97 & $-0,46$ & 0,15 & 0,57 & 0,80 \\
PAS - Preferred & & & & & & \\
Advice & 27,32 & 4,35 & $-2,86$ & 10,67 & 0,52 & 0,87 \\
Investigation & 51,43 & 6,73 & $-3,31$ & 13,91 & 0,51 & 0,91 \\
Station duties & 27,82 & 3,93 & $-3,00$ & 11,69 & 0,47 & 0,84 \\
Crime prevention & 18,14 & 2,78 & $-2,83$ & 11,00 & 0,48 & 0,77 \\
Assistance & 13,27 & 2,53 & $-1,85$ & 3,52 & 0,49 & 0,73 \\
Family issues & 22,77 & 3,61 & $-2,83$ & 10,33 & 0,63 & 0,89 \\
Security & 13,75 & 2,32 & $-2,62$ & 7,58 & 0,62 & 0,82 \\
\hline
\end{tabular}

Table 1 shows that acceptable Cronbach alpha coefficients were obtained on all the dimensions of the PAS, varying from 0,67 to 0,93 (see Nunnally \& Bernstein, 1994). Most of the interitem correlation coefficients were acceptable, although values higher than the cut-off point of 0,50 (Clark \& Watson, 1995) were obtained for some of the scales. The results of all the items of the PAS - Preferred were relatively skew. Scores on the other dimensions seem to be distributed normally (skewness and kurtosis < 1).

Descriptive statistics, Cronbach alpha coefficients and the interitem correlation coefficients of the PAS for 418 community members in the Rustenburg area are reported in Table 2.

Table 2 shows acceptable Cronbach alpha coefficients, varying from 0,67 to 0,93 (see Nunnally \& Bernstein, 1994). The mean inter-item correlations are acceptable, although some were higher than the guideline of 0,50 (Clarke \& Watson, 1995). It is evident from Table 2 that dimensions for the first part of the Public Attitude Survey (PAS - Present) are distributed relatively normally, with low skewness and kurtosis. However, the second half of the survey (PAS - Preferred) shows relatively high skewness and kurtosis. Based on the results in Table 2 the internal consistencies of the factors of the PAS are acceptable.

TABLE 2

DESCRIPTIVE STATISTICS, CRONBACH ALPHA COEFFICIENTS AND INTER-ITEM CORRELATION COEFFICIENTS OF THE PAS FOR COMMUNITY MEMBERS IN THE RUSTENBURG AREA $(N=418)$

\begin{tabular}{lcccccc}
\hline Test and items & Mean & $\boldsymbol{S D}$ & Skewness & Kurtosis & Inter-item $\boldsymbol{r}$ & $\alpha$ \\
\hline PAS - Present & & & & & & \\
Advice & 13,78 & 5,80 & 0,51 & $-0,50$ & 0,53 & 0,87 \\
Investigation & 28,27 & 10,58 & 0,22 & $-0,66$ & 0,55 & 0,93 \\
Station duties & 15,87 & 5,87 & 0,37 & $-0,54$ & 0,52 & 0,87 \\
Crime prevention & 9,48 & 4,13 & 0,59 & $-0,34$ & 0,46 & 0,77 \\
Assistance & 6,99 & 2,95 & 0,43 & $-0,50$ & 0,40 & 0,67 \\
Family issues & 13,73 & 5,29 & 0,21 & $-0,76$ & 0,45 & 0,80 \\
Security & 9,40 & 3,48 & $-0,12$ & $-0,83$ & 0,57 & 0,80 \\
PAS - Preferred & & & & & & \\
Advice & 28,04 & 2,89 & $-1,85$ & 4,05 & 0,52 & 0,87 \\
Investigation & 52,19 & 5,14 & $-2,58$ & 7,56 & 0,51 & 0,91 \\
Station duties & 27,99 & 3,49 & $-2,17$ & 5,00 & 0,47 & 0,84 \\
Crime prevention & 18,70 & 2,42 & $-2,61$ & 8,50 & 0,48 & 0,77 \\
Assistance & 13,97 & 1,96 & $-2,29$ & 5,72 & 0,49 & 0,73 \\
Family issues & 23,54 & 2,63 & $-1,96$ & 3,57 & 0,63 & 0,89 \\
Security & 13,72 & 2,09 & $-2,19$ & 5,92 & 0,62 & 0,82 \\
\hline
\end{tabular}

Differences between present and preferred priorities on the dimensions of the PAS for duties performed by the police, for community members $(N=418)$ and for police members $(N=101)$ in the Rustenburg area are reported in Table 3.

Table 3 shows practically significant differences (of large effect $d \geq 0,80$ ) on all the dimensions of the PAS for both the community and police members in the Rustenburg area regarding preferred priorities. However, Table 3 also shows differences between the community's view and that of the police on both the present and preferred dimensions of the PAS.

An inspection of Table 3 shows the following differences between the present and preferred priorities for the community and police members respectively: To receive advice regarding crime prevention achieve the largest difference score for the community $(2,46)$. Investigation of crime represents the largest preferred priority for police members $(1,55)$. Assistance is the second largest

TABLE 3

DIFFERENCES BETWEEN PRESENT AND PREFERRED PRIORITIES FOR THE PAS DIMENSIONS

\begin{tabular}{|c|c|c|c|c|c|c|c|c|c|c|}
\hline & \multicolumn{5}{|c|}{ Community Members' Perceptions $(N=418)$} & \multicolumn{5}{|c|}{ Police Members' Perceptions $(N=101)$} \\
\hline & \multicolumn{2}{|c|}{ Present } & \multicolumn{2}{|c|}{ Preferred } & \multirow[t]{2}{*}{$d$} & \multicolumn{2}{|c|}{ Present } & \multicolumn{2}{|c|}{ Preferred } & \multirow[t]{2}{*}{$d$} \\
\hline & Mean & $S D$ & Mean & $S D$ & & Mean & $S D$ & Mean & $S D$ & \\
\hline Advice & 13,78 & 5,80 & 28,04 & 2,89 & $2,46^{* *}$ & 20,66 & 5,09 & 27,32 & 4,35 & $1,31^{* *}$ \\
\hline Investigation & 28,27 & 10,58 & 52,19 & 5,14 & $2,27^{* *}$ & 37,98 & 8,68 & 51,43 & 6,73 & $1,55^{* *}$ \\
\hline Station duties & 15,87 & 5,87 & 27,99 & 3,49 & $2,07^{* *}$ & 20,16 & 5,30 & 27,82 & 3,93 & $1,46^{* *}$ \\
\hline Crime prevention & 9,48 & 4,13 & 18,70 & 2,42 & $2,23^{* *}$ & 13,00 & 3,94 & 18,14 & 2,78 & $1,31^{* *}$ \\
\hline Assistance & 6,99 & 2,95 & 13,97 & 1,96 & $2,37^{* *}$ & 9,19 & 2,78 & 13,27 & 2,53 & 1,47 ** \\
\hline Family issues & 13,73 & 5,29 & 23,54 & 2,63 & $1,85^{* *}$ & 16,86 & 4,52 & 22,77 & 3,61 & $1,31^{* *}$ \\
\hline Security & 9,40 & 3,48 & 13,72 & 2,09 & $1,24^{* *}$ & 10,80 & 2,97 & 13,75 & 2,32 & $0,99 * *$ \\
\hline
\end{tabular}

* Practically significant difference: $d \geq 0,50$ (medium effect)

** Practically significant difference: $d \geq 0,80$ (large effect) 
difference of both community $(2,37)$ and police members $(1,47)$. Not shown in Table 3 are the weighted means of each dimension (i.e. the dimension score divided by the number of items on the dimension). The weighted means indicate that to investigate crime and to attend to family issues were the highest preferences of community members, while investigating crime and station duties were the highest priorities for police members.

Differences between present and preferred priorities on all 38 PAS items for duties performed by the police, for community members $(N=418)$ and for police members $(N=101)$ in the Rustenburg area are reported in Table 4.

Table 4 shows significantly higher scores (mainly of large effect) for community members in the Rustenburg area regarding their preferred priorities for police duties. Police members in the Rustenburg area achieved higher scores (practically significant, medium and large effects) on their preferred priorities compared to their present priorities. Practically significant differences of medium effect were obtained on only two items, namely Transport prisoners and Gun licences. Duties such as to advise businesses and homeowners on crime prevention, responding to emergencies, patrolling on foot and vice control are the highest preferred priorities as indicated by the community. The police on the other hand considered duties such as arresting offenders, responding to emergencies, finding stolen property and giving feedback to victims as their highest priorities. It is interesting that the community's priorities for the different items are significantly higher than those of the police, except for one item, namely to protect important people.

Differences between the way in which Afrikaans-, English-, and Tswana-speaking community members currently view the police and what they prefer the police to do are reported in Table 5 .

TABLE 4

DIFFERENCES BETWEen PRESENT AND PREFERRED PRIORITIES FOR PAS ITEMS IN THE RUSTENBURG AREA

\begin{tabular}{|c|c|c|c|c|c|c|c|c|c|c|}
\hline & \multicolumn{5}{|c|}{ Community Members' Perceptions $(N=418)$} & \multicolumn{5}{|c|}{ Police Members' Perceptions $(N=101)$} \\
\hline & \multicolumn{2}{|c|}{ Present } & \multicolumn{2}{|c|}{ Preferred } & \multirow[t]{2}{*}{$d$} & \multicolumn{2}{|c|}{ Present } & \multicolumn{2}{|c|}{ Preferred } & \multirow[t]{2}{*}{$d$} \\
\hline & Mean & $S D$ & Mean & $S D$ & & Mean & $S D$ & Mean & $S D$ & \\
\hline Advise businesses & 2,07 & 1,20 & 4,64 & 0,64 & 2,14 ** & 3,43 & 1,04 & 4,57 & 0,79 & $1,10^{* *}$ \\
\hline Advise people & 2,29 & 1,31 & 4,65 & 0,74 & 1,80 ** & 3,68 & 1,05 & 4,57 & 0,85 & $0,85^{* *}$ \\
\hline Organise meetings & 2,23 & 1,30 & 4,58 & 0,75 & 1,81 * * & 3,46 & 1,07 & 4,59 & 0,73 & 1,06 * * \\
\hline Advise local schools & 2,65 & 1,44 & 4,76 & 0,55 & $1,47 * *$ & 3,52 & 1,15 & 4,59 & 0,79 & 0,93 * * \\
\hline Support victims & 2,31 & 1,31 & 4,70 & 0,62 & $1,82 * *$ & 3,36 & 1,08 & 4,48 & 0,82 & 1,04 ** \\
\hline Advice on home security & 2,22 & 1,30 & 4,72 & 0,60 & 1,92 ** & 3,20 & 1,25 & 4,52 & 0,90 & $1,06^{* *}$ \\
\hline Take statements & 2,58 & 1,32 & 4,72 & 0,64 & 1,62 ** & 3,52 & 1,19 & 4,61 & 0,69 & 0,92 ** \\
\hline Collect information & 2,42 & 1,25 & 4,73 & 0,70 & $1,85^{* *}$ & 3,30 & 1,23 & 4,64 & 0,84 & 1,09 * * \\
\hline Collect evidence & 2,37 & 1,28 & 4,73 & 0,61 & 1,84 ** & 3,50 & 1,09 & 4,61 & 0,72 & 1,02 ** \\
\hline Protect crime scenes & 2,53 & 1,37 & 4,71 & 0,66 & 1,59 ** & 3,57 & 1,11 & 4,66 & 0,75 & 0,98 ** \\
\hline Interview suspect & 2,64 & 1,37 & 4,71 & 0,63 & 1,51 * * & 3,64 & 1,08 & 4,64 & 0,72 & 0,93 * * \\
\hline Arrest offenders & 2,96 & 1,38 & 4,83 & 0,50 & 1,36 * * & 3,59 & 0,97 & 4,73 & 0,69 & 1,18 ** \\
\hline Respond to emergencies & 2,26 & 1,30 & 4,77 & 0,61 & 1,93 ** & 3,30 & 1,05 & 4,75 & 0,62 & 1,38 ** \\
\hline Investigate crime & 2,45 & 1,25 & 4,73 & 0,62 & 1,82 ** & 3,27 & 1,09 & 4,68 & 0,74 & $1,05^{*}$ * \\
\hline Prepare cases for court & 2,66 & 1,31 & 4,67 & 0,72 & 1,53 * * & 3,50 & 1,02 & 4,79 & 0,55 & 1,27 * * \\
\hline Handle lost/found property & 2,36 & 1,28 & 4,68 & 0,75 & 1,81 * * & 3,50 & 1,17 & 4,71 & 0,63 & 1,03 ** \\
\hline Find stolen property & 2,40 & 1,31 & 4,74 & 0,67 & $1,79 * *$ & 3,14 & 1,09 & 4,66 & 0,75 & $1,40^{* *}$ \\
\hline Transport prisoners & 3,19 & 1,40 & 4,66 & 0,72 & $1,05^{* *}$ & 3,91 & 1,12 & 4,68 & 0,77 & 0,69 * \\
\hline Check offenders out on bail & 2,58 & 1,36 & 4,65 & 0,98 & $1,46^{* *}$ & 3,02 & 1,30 & 4,46 & 0,84 & 1,11 * * \\
\hline Give formal warnings & 2,59 & 1,31 & 4,67 & 0,71 & $1,59 * *$ & 3,09 & 1,10 & 4,48 & 0,88 & $1,26^{* *}$ \\
\hline Patrols other than on foot & 2,44 & 1,43 & 4,78 & 0,56 & $1,64^{* *}$ & 3,27 & 1,17 & 4,66 & 0,75 & 1,19 * * \\
\hline Deal with disturbances & 2,44 & 1,33 & 4,66 & 0,78 & 1,67 * * & 2,89 & 1,21 & 4,25 & 1,14 & 1,12 ** \\
\hline Patrol on foot & 2,10 & 1,30 & 4,62 & 0,81 & 1,94 ** & 2,61 & 1,45 & 4,36 & 0,94 & 1,21 ** \\
\hline Search people/cars/places & 2,59 & 1,41 & 4,65 & 0,77 & $1,46^{* *}$ & 3,52 & 1,17 & 4,75 & 0,62 & 1,05 * * \\
\hline Gun licences & 2,35 & 1,38 & 4,66 & 0,75 & 1,67 ** & 3,59 & 1,26 & 4,36 & 1,10 & $0,61^{*}$ \\
\hline Control vice & 1,93 & 1,17 & 4,65 & 0,81 & 2,32 ** & 2,80 & 1,23 & 4,39 & 1,06 & 1,29 ** \\
\hline Control liquor licences & 2,63 & 1,40 & 4,66 & 0,79 & $1,45^{* *}$ & 3,50 & 1,07 & 4,59 & 0,73 & 1,02 * * \\
\hline Issue restraining orders & 2,56 & 1,34 & 4,67 & 0,68 & 1,58 * * & 2,98 & 1,17 & 4,27 & 1,13 & 1,10 ** \\
\hline Death messages & 3,06 & 1,48 & 4,73 & 0,63 & 1,13 * * & 3,59 & 1,18 & 4,57 & 0,76 & 0,83 * * \\
\hline Family violence & 2,78 & 1,43 & 4,69 & 0,73 & $1,34^{* *}$ & 3,68 & 1,12 & 4,57 & 0,78 & 0,80 ** \\
\hline Traffic accidents & 3,08 & 1,47 & 4,78 & 0,55 & $1,16^{* *}$ & 3,66 & 1,10 & 4,73 & 0,59 & 0,97 * * \\
\hline Missing persons & 2,58 & 1,39 & 4,72 & 0,65 & $1,54^{* *}$ & 2,89 & 1,28 & 4,64 & 0,84 & $1,37^{* *}$ \\
\hline Police community centres & 2,58 & 1,46 & 4,75 & 0,63 & $1,49 * *$ & 3,50 & 1,17 & 4,73 & 0,69 & 1,05 * * \\
\hline Protect important people & 3,45 & 1,49 & 4,45 & 1,03 & $0,67^{*}$ & 3,46 & 1,34 & 4,55 & 0,93 & 0,81 * * \\
\hline Control crowds & 3,08 & 1,50 & 4,68 & 0,74 & 1,07 * * & 3,50 & 1,29 & 4,57 & 0,95 & 0,83 ** \\
\hline Take care of prisoners & 2,87 & 1,41 & 4,59 & 0,83 & 1,22 ** & 3,84 & 0,91 & 4,64 & 0,78 & $0,88^{* *}$ \\
\hline Deal with sexual violence & 2,76 & 1,40 & 4,74 & 0,71 & 1,41 * * & 3,73 & 0,95 & 4,73 & 0,73 & 1,05 * * \\
\hline Give feedback to victims & 2,50 & 1,40 & 4,77 & 0,62 & 1,62 ** & 3,14 & 1,29 & 4,71 & 0,67 & 1,22 ** \\
\hline
\end{tabular}

* Practically significant difference: $d \geq 0,50$ (medium effect)

** Practically significant difference: $d \geq 0,80$ (large effect) 
TABLE 5

Differences for the PAS Between language GROUPS IN THE RUSTENBURG AREA

\begin{tabular}{lccccc}
\hline Items & $\begin{array}{c}\text { Mean }- \\
\text { Afrikaans }\end{array}$ & $\begin{array}{c}\text { Mean }- \\
\text { English }\end{array}$ & $\begin{array}{c}\text { Mean }- \\
\text { Tswana }\end{array}$ & $\boldsymbol{p}$ & Root MSE \\
\hline PAS - Present & & & & & \\
Advice & 12,50 & 12,45 & 14,49 & $0,02^{*}$ & 5,73 \\
Investigation & 27,39 & 26,16 & 29,18 & 0,11 & 10,53 \\
Station duties & 15,31 & 14,46 & 16,48 & $0,04^{*}$ & 5,83 \\
Crime prevention & 8,61 & 8,77 & 9,89 & 0,06 & 4,11 \\
Assistance & 6,72 & 6,49 & 7,22 & 0,18 & 2,94 \\
Family issues & 13,47 & 12,57 & 14,19 & 0,09 & 5,26 \\
Security & 8,53 & 8,59 & 9,84 & $0,01^{*}$ & 3,43 \\
PAS - Preferred & & & & & \\
Advice & 27,78 & 27,61 & 28,25 & 0,24 & 2,88 \\
Investigation & 51,56 & 51,86 & 52,45 & 0,49 & 5,15 \\
Station duties & 26,64 & 27,77 & 28,31 & $0,03^{*}$ & 3,46 \\
Crime prevention & $17,72 \mathrm{~b}$ & 18,59 & $18,92 \mathrm{a}$ & $0,02^{*}$ & 2,40 \\
Assistance & $13,00 \mathrm{~b}$ & 14,06 & $14,11 \mathrm{a}$ & $0,01^{*}$ & 1,93 \\
Family issues & 22,67 & 23,49 & 23,71 & 0,09 & 2,62 \\
Security & 12,97 & 13,68 & 13,87 & 0,06 & 2,08 \\
\hline
\end{tabular}

a Practically significant difference for language (in row) where $\mathrm{b}$ (medium effect, $d \geq$ 0,50 ) or c (large effect, $d \geq 0,80$ ) are indicated.

* Statistically significant $p \leq 0,05$

Table 5 shows no practically significant difference between the three different language groups regarding how they currently view the police. Table 5 further only shows practically significant differences (of medium effect) between the Afrikaans- and Tswana-speaking participants regarding what they prefer the police to do in terms of crime prevention and assistance.

Perceptions of how the police members in the Rustenburg area view the community as well as how they expect the community to co-operate are reported in Table 6.

\section{TABLE 6}

CONTACT WITH THE COMMUNITY FOR POLICE OFFICERS IN THE RUSTENBURG AREA

\begin{tabular}{|c|c|c|}
\hline Item & Frequency & Percentage \\
\hline \multicolumn{3}{|c|}{$\begin{array}{l}\text { The amount of trust in the community to } \\
\text { co-operate }\end{array}$} \\
\hline Very low & 8 & 8 \\
\hline Low & 15 & 15 \\
\hline Average & 54 & 55 \\
\hline High & 14 & 14 \\
\hline Very high & 8 & 8 \\
\hline \multicolumn{3}{|c|}{ To what extent community needs are satisfied } \\
\hline Almost nothing - Not at all & 6 & 6 \\
\hline Average & 59 & 60 \\
\hline To a large extent & 34 & 34 \\
\hline \multicolumn{3}{|c|}{$\begin{array}{l}\text { The overall performance in serving the } \\
\text { community }\end{array}$} \\
\hline Very low & 5 & 5 \\
\hline Low & 9 & 9 \\
\hline Average & 37 & 37 \\
\hline High & 30 & 30 \\
\hline Very high & 18 & 18 \\
\hline \multicolumn{3}{|c|}{ Reliability of media in reporting crime } \\
\hline Very low & 5 & 5 \\
\hline Low & 21 & 22 \\
\hline Average & 41 & 42 \\
\hline High & 23 & 24 \\
\hline Very high & 7 & 7 \\
\hline
\end{tabular}

Table 6 shows that $8 \%$ of the police members in the Rustenburg area do not trust the community to co-operate, while another $8 \%$ believe the community will support them all the way. Furthermore, $55 \%$ believe that they can expect only moderate support from the community. Six percent of the police respondents report that they do not satisfy the needs of the community at all, while $34 \%$ believe they satisfy the community's needs to a large extent. Also, $60 \%$ feel that they satisfy the community needs at least to a certain extent. The majority of respondents believe they perform well in serving the community and $26 \%$ believe that the media are not very reliable in reporting crime.

Perceptions of community members in the Rustenburg area who had contact with the police during the previous 12 months are reported in Table 7.

TABLE 7

Community Members In THE RUSTENBURg AREA WHo HAD CONTACT WITH THE SAPS $(\mathbf{N}=152)$

\begin{tabular}{|c|c|c|}
\hline Item & Frequency & Percentage \\
\hline \multicolumn{3}{|l|}{ Level of competence - police officer } \\
\hline No opinion & 8 & 5 \\
\hline Low - very low & 67 & 44 \\
\hline Average & 60 & 40 \\
\hline High - very high & 16 & 11 \\
\hline \multicolumn{3}{|l|}{ Helpfulness } \\
\hline No opinion & 6 & 4 \\
\hline Low - very low & 72 & 48 \\
\hline Average & 44 & 29 \\
\hline High - very high & 28 & 19 \\
\hline \multicolumn{3}{|l|}{ Interest in the situation } \\
\hline No opinion & 7 & 5 \\
\hline Low - very low & 76 & 51 \\
\hline Average & 46 & 31 \\
\hline High - very high & 21 & 14 \\
\hline \multicolumn{3}{|l|}{ Courtesy/Respectfulness } \\
\hline No opinion & 6 & 4 \\
\hline Low - very low & 63 & 42 \\
\hline Average & 45 & 30 \\
\hline High - very high & 36 & 24 \\
\hline \multicolumn{3}{|l|}{ Fair } \\
\hline No opinion & 7 & 5 \\
\hline Low - very low & 61 & 41 \\
\hline Average & 51 & 34 \\
\hline High - very high & 31 & 21 \\
\hline \multicolumn{3}{|l|}{ Level of trust } \\
\hline No opinion & 6 & 4 \\
\hline Low - very low & 70 & 47 \\
\hline Average & 45 & 30 \\
\hline High - very high & 29 & 19 \\
\hline \multicolumn{3}{|l|}{ Satisfaction with the service provided } \\
\hline Low - very low & 89 & 60 \\
\hline Average & 45 & 30 \\
\hline High - very high & 14 & 9 \\
\hline \multicolumn{3}{|l|}{ Satisfaction with responding officer } \\
\hline Low - very low & 76 & 52 \\
\hline Average & 45 & 31 \\
\hline High - very high & 25 & 17 \\
\hline \multicolumn{3}{|l|}{ Reasons for not satisfied } \\
\hline Slow response time & 80 & \\
\hline Officer did not follow up & 34 & \\
\hline Officer was rude & 23 & \\
\hline Officer seemed not to care & 38 & \\
\hline Officer did not listen to the victim & 7 & \\
\hline No arrests were made & 40 & \\
\hline
\end{tabular}


Table 7 shows that as many as $44 \%$ of the community respondents who had contact with the police within the last 12 months believe that the police officer with whom they had contact is incompetent. Only $11 \%$ regard police officers as very competent, while $40 \%$ of the respondents view police officers as competent only to a certain extent. Only 19\% of the respondents experience the police as very helpful. Furthermore, $51 \%$ of the respondents indicate that the police had very little interest in their situations. Only $24 \%$ experience the police as very respectful. Thirty-four percent of the community members feel that the police are fair but only to a certain extent. Also, $19 \%$ of the respondents feel that they can really trust the police, while $47 \%$ feel they cannot really trust the police.

Only $9 \%$ are very satisfied with the provided service. Regarding the responding officer, $52 \%$ indicate that they are dissatisfied, $31 \%$ are happy but not entirely satisfied and only $17 \%$ are very satisfied. Table 7 also indicates that 80 of the respondents are dissatisfied because of slow response time. Thirty-four of the respondents indicate that the police officer does not follow up the case and 40 indicate that they are unhappy because no arrests are made.

Satisfaction with the overall service of the police, neighbourhood concerns, confidence in the SAPS as well as the sources of information about the police for community members in the Rustenburg area are reported in Table 8.

TABLE 8

OVERALL SERVICE, NEIGHBOURHOOD CONCERNS, CONFIDENCE

IN THE SAPS AND INFORMATION ABOUT THE POLICE FOR COMMUNITY MEMBERS IN THE RUSTENBURG AREA

Item $\quad$ Frequency Percentage

Overall service of the SAPS

$\begin{array}{lcc}\text { Poor - very poor } & 165 & 40 \\ \text { Average } & 182 & 44 \\ \text { Good - very good } & 66 & 12 \\ \text { Police officers seen in the neighbourhood } & & \\ \text { Generally not seen } & 148 & 36 \\ \text { 1-3 times per week } & 102 & 24 \\ 4-10 \text { times per week } & 62 & 15 \\ \text { More than 10 times per week } & 103 & 25\end{array}$

Safety and security of the neighbourhood

$\begin{array}{lcc}\text { Unsafe - very unsafe } & 174 & 42 \\ \text { Fairly safe } & 152 & 37 \\ \text { Safe - very safe } & 87 & 21\end{array}$

Is the neighbourhood more safe, about as safe or less safe?

More safe

About as safe

200

Less safe

Where to go in a crime situation

Police

Private security company

Local civic

Community policing forum

Where people get their information

Radio

Newspapers

Television

Friends/relatives

Police friends/relatives

Community policing forums

Community policing forums
Table 8 shows that $40 \%$ of the respondents are unhappy and/or dissatisfied with the overall service of the police. A total of $36 \%$ indicate that the police are generally not seen in their neighbourhoods, while others (25\%) indicate that they see the police 10 times or more per week in their neighbourhoods. Thirty seven percent indicate that their neighbourhood is fairly safe and $48 \%$ report that their neighbourhood is about as safe as other neighbourhoods. Also, $74 \%$ indicate that they would go to the police in instances of crime. Table 8 also shows that the radio (185 respondents), newspapers (129 respondents) and television (194 respondents) are the most important sources of information regarding information about the SAPS in the Rustenburg area.

\section{DISCUSSION}

This study was based on the premise that the ideal outcome for community policing is for officers and citizens to interact in continuous co-operative efforts to reduce crime in South Africa. Significant differences were found between the present and preferred functions of the police from the perspective of both police and community members. For the community the strongest effects were obtained regarding advice, assistance, investigation and crime prevention. For police members the strongest effects were obtained regarding investigation, assistance and station duties. One could argue that the community has almost unrealistic high expectations of the police. However, given the high crime rate in South Africa the concomitant expectations of the police are understandable.

The results showed no significant differences between Afrikaans-, English- and Tswana-speaking community members regarding their present perception of duties performed by the police. The only significant differences (of medium effect) were between Afrikaans- and Tswana-speaking people regarding their expectations of crime prevention and assistance.

The results indicated that the community regarded protecting important people, attending to traffic accidents and keeping crowds under control at public events as the most important current police activities. However, they rated "arrest offenders" as their highest preferred priority. The police, on the other hand rated transporting and taking care of prisoners as their highest present priorities, and preparing cases for court as their highest preferred priority.

The above ratings of both the public and the police are inconsistent with other studies of this kind (e.g. Beck et al., 1999). According to Beck et al. (1999), responding to emergencies were rated as the highest present and preferred police activity by both the public and the police elsewhere in the world. However, it is important to remember that although community policing can be compared globally, circumstances and priorities may differ from country to country. For instance, South Africa has in recent years transformed from a racially divided country to a democracy. The police also changed from a "police force" to a "police service", and the main focus became visible policing rather than focusing on other activities as well (Louw, 1997).

The police represent the first line of the criminal justice process and therefore it can be argued that the better the police perform in collecting evidence on or around the crime scene, the better the chance that the criminal will be prosecuted. In 1995 only one quarter of all robberies, one fifth of housebreakings, one tenth of vehicle thefts and about $50 \%$ of murders were resolved (Louw, 1997). It can be argued that for police to "solve" crimes they should produce the necessary evidence to clear crimes from their books. That may explain why they regarded "prepare cases for court" as their highest preferred priority. From the perspective of police members and the community, too many 
criminals go free because of insufficient evidence. In a study of 2396 police members in South Africa, Pienaar (2002) found that seeing criminals go free is a severe stressor for police members. According to Louw (1997), inherent weaknesses in the South African criminal justice system contribute to a situation of crisis proportions. She ascribed the high crime rates in the country to these weaknesses.

On the other hand, the community rated vice control and advice to businesses as their lowest present police priorities. To protect important people was scored as their lowest preferred priority. However, the police scored patrol on foot as the lowest present priority and dealing with disturbances as their lowest preferred priority. A comparison between the present and preferred priorities of both police members and community members shows that both achieved large difference scores. Both groups regarded the improvement of the overall service delivery of the SAPS as important.

Although both the public and the police indicated that the service delivery of the SAPS should improve, it is possible that the police succumbed to the expectations of the public. The results of the PAS for police officials show a significant difference between their present and preferred perceptions of their functions. It should also be kept in mind that the police are constantly measuring their own performance. One way in which such measurement takes place is by the use of non-scientific questionnaires asking the public how they perform.

The overall analysis of the PAS shows relatively low congruency between what the public expects from the SAPS and the perceptions of police officials regarding their functions. Consequently, the results show that the preferred expectations of the community were very skewly distributed (skewness $>1$ ), suggesting unrealistic expectations of the community regarding the duties performed by the SAPS.

Transformation in the SAPS may be regarded as a contributing factor to the inconsistency of what the public expects from the SAPS and the perception of the police members of what their priorities are. With South Africa's long history of apartheid and its effect on the former way of policing, the new police service (SAPS) is under extreme pressure to transform. Louw (1997) argues that the demands of the transition from a police force to a police service have made it difficult for the police to combat crime. In turn it can be argued that the capacity SAPS to transform may be impaired by the high crime rates.

It can be argued that the mass media contribute to the unrealistic expectations among the public. The results show that the majority of the community respondents get their information from the mass media. Louw (1997) argues that in the absence of direct experience with the police, the mass media has a strong influence on the development of public attitudes about policing and police work and it sometimes happens that details get lost due to reporting. Eight percent of the police members expect the community to co-operate completely; a further $8 \%$ do not expect the community to co-operate at all. Fifty five percent of the police respondents expect the community to co-operate, but not completely. It appears that these police officers expect the community only to co-operate when it is in their interest and not to help with crime prevention in general. However, $47 \%$ of the community members who had contact with the police indicated that their confidence in the police is low to very low. A further $30 \%$ indicated that they trust the police only to a certain extent. This may be the reason why police members do not expect the community to co-operate completely.

It is alarming that $44 \%$ of the community members in the Rustenburg area who had contact with the police regarded the level of competence of police officers as low. A total of $48 \%$ reported that police officers were not helpful, while $51 \%$ indicated that police officers show little interest in their situation. Furthermore, $47 \%$ indicated low trust in the police, while $60 \%$ were not satisfied with the service they received from the police. A total of $52 \%$ percent of the community members reported that they were not satisfied with the responding officer. The main reason for their low level of satisfaction was slow response time.

\section{RECOMMENDATIONS}

Firstly, if police officials in the Rustenburg area want to effectively engage and consult with the community, they should focus on what the community expects from them as police, seeing that there is a discrepancy between the present and preferred priorities regarding the police as indicated by the public. It can be argued that the removal of discrepancies between the current and preferred priorities is the first step to successful consultation and engagement, as it identifies areas in which the community in the Rustenburg area seem to desire change. Secondly, because it seems that the community has unrealistic expectations of the SAPS, steps should be taken to help the community develop realistic expectations. In the process they should be encouraged to accept responsibility for helping the police combat crime.

The relationship between what the public expects of the police and the perception police members have of their functions should be investigated in all the provinces of South Africa. Interventions to increase the trust between the police and the community should be researched.

\section{REFERENCES}

Barlow, D.E. \& Barlow, M.H. (1999). A political economy of community policing. Policing: An International Journal of Police Strategies and Management, 22, 646-674.

Beck, K., Boni, N. \& Packer, J. (1999). The use of public attitude surveys: What can they tell police managers? Policing: An International Journal of Police Strategies and Management, 22, 191-216

Carter, D.L. (1985). Hispanic perception of police performance: An empirical assessment. Journal of Criminal Justice, 13, 487-500.

Choong, P. (2001). Preventing or fixing a problem: a marketing manager's dilemma revisited. Journal of Service Marketing. 15, 99-112.

Clark, L.A. \& Watson, D. (1995). Construct validity: Basic issues in objective scale development. Psychological Assessment, 7, 309-319

Cohen, J. (1988). Statistical power analysis for behavioral sciences ( $2^{\text {nd }}$ ed.). Hillsdale, NJ: Lawrence Erlbaum \& Associates.

Couper, D.C. (1983). How to rate your local police. Washington, DC: US Department of Justice.

Department of Safety and Security (1997). Community policing: Policy framework and guidelines. A manual for the South African Police Service.

Erez, E. (1984). Self-defined "desert" and citizens' assessment of the police. The Journal of Criminal Law and Criminology, 75, 1276-1299.

Fosam, E.B. \& Grimsley, M.F.J. (1998). Exploring models for employee satisfaction with particular reference to a police force. Total Quality Management, 11(2/3), 235. Retrieved October 02, 2002, from ACADEMIC SEARCH PRIMIER database on the World Wide Web: http://www.academicsearchprimier.com

Flanagan, T.J. (1985). Consumer perspectives on police operational strategy. Journal of Police Science and Administration, 13, 10-21.

Hero, R.E. \& Durand, R. (1985). Explaining evaluations of urban service: A comparison of some alternative models. Urban Affairs Quarterly, 30, 344-354.

Hubbert, A.R., Sehorn, A.G. \& Brown, S.W. (1995). Service expectations: The customer versus the provider. International Journal of Service Industry Management, 6, 6-21. 
Louw, A. (1997). Surviving the transition: Trends and perceptions of crime in South Africa. Social Indicators Research, 41, 137-168.

Murty, S., Komanduri, R., Julian, B. \& Smith, J.B. (1990). The image of the police in Black Atlanta communities. Journal of Police Science and Administration, 17, 280-287.

Nunnally, J.C. \& Bernstein, I.H. (1994). Psychometric theory (3 $3^{\text {rd }}$ ed.). New York: McGraw-Hill.

Pelser, E., Schnetler, J. \& Louw, A. (2002). Not everybody's business: Community policing in the SAPS' priority areas. Brooklyn Square, Pretoria: Institute for Security Studies.

Pienaar, J. (2002). Coping, stress and suicide ideation in the South African Police Service. Unpublished doctoral thesis, PU for CHE, Potchefstroom.

Radelet, L. (1986). The police and the community. New York: Macmillan.

Reisig, M.D. \& Chandek, M.S. (2001). The effects of expectancy disconfirmation on outcome satisfaction in police-citizen encounters. Policing: An International Journal of Police Strategies and Management, 24, 88-99.

Reisig, M.D. \& Giacomazzi, A.L. (1998). Citizen perceptions of community policing: Are attitudes towards police important? Policing: An International Journal of Police Strategies and Management, 21, 547-561.

Rothmann, S. (2002). Attitudes towards community policing in the North West Province. Unpublished research report. Potchefstroom: PU for CHE.

SAS Institute, (2000). The SAS System for Windows: Release 8.01. Cary, NC: SAS Institute Inc.

Shaughnessy, J.J. \& Zechmeister, E.B. (1997). Research methods in psychology (4th ed.). New York: McGraw-Hill.

Steyn, H.S. (1999). Praktiese betekenisvolheid: Die gebruik van effekgroottes. Wetenskaplike bydraes - Reeks B: Natuurwetenskappe Nr. 117. Potchefstroom: PU vir CHO.

Worrall, J.L. (1999). Public perceptions of police efficacy and image: The "fuzziness" of support for the police. American Journal of Criminal Justice, 24 (1), 47-66. 